\title{
THE WAR POWERS RESOLUTION: REASSESSING THE CONSTITUTIONAL BALANCE OF POWER
}

\author{
A Thesis \\ Presented to \\ The Faculty of California Polytechnic State University, \\ San Luis Obispo
}

\author{
In Partial Fulfillment \\ of the Requirements for the Degree \\ Master of Arts in History
}

by

Kasey Elizabeth Cable

December 2009 
(C) 2009

Kasey Elizabeth Cable

ALL RIGHTS RESERVED 


\section{COMMITTEE MEMBERSHIP}

TITLE:

The War Powers Resolution: Reassessing the

Constitutional Balance of Power

AUTHOR: $\quad$ Kasey Elizabeth Cable

DATE SUBMITTED: $\quad$ December 2009

COMMITTEE CHAIR: $\quad$ Thomas Trice, PhD. Professor of History

COMMITTEE MEMBER: John Snetsinger, PhD. Professor of History

COMMITTEE MEMBER: Ronald Den Otter, PhD. Professor of Political Science 


\begin{abstract}
The War Powers Resolution: Reassessing the Constitutional Balance of Power Kasey Elizabeth Cable
\end{abstract}

This thesis is an analysis of the War Powers Resolution of 1973 and the impact it held on the role of Congress and the President in entering war. More specifically, this thesis takes a look at President Richard M. Nixon's influence on the $93^{\text {rd }}$ Congress's decision to pass the War Powers Resolution after multiple failed attempts at similar legislation. Through a major domestic policy blunder, the Watergate break-in, and a foreign policy disaster, the on-going war in Vietnam, opposition to Nixon's residential conduct united both the House and the Senate and resulted in legislation that would attempt to restore the Constitutional balance of power. 


\section{TABLE OF CONTENTS}

Page

INTRODUCTION........................................................ 1

FOUNDERS DISCUSSION: WAR POWERS ORIGINAL INTENT AND THE

BALANCE OF POWER ................................................. 5

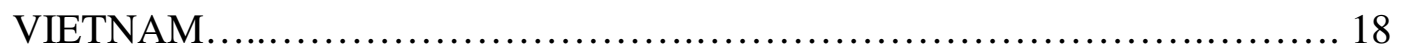

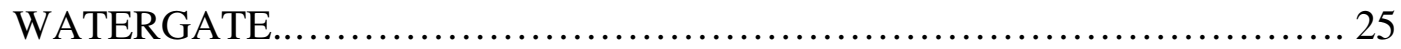

THE WAR POWERS RESOLUTION..................................... 32

CONSTUTIONAL CONTROVERSY: THE BALANCE OF POWER..................41

WAR POWERS RESOLUTION IMPLEMENTATION........................44

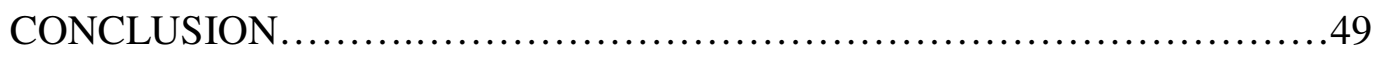

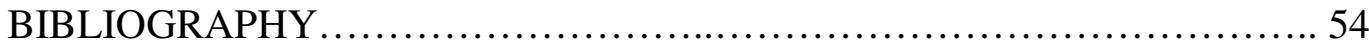




\section{INTRODUCTION}

On December 7, 1941, President Franklin D. Roosevelt called together an emergency session of Congress. The United States had been attacked at Pearl Harbor by the Japanese and America could no longer feign an attempt to stay out of the Second World War. Congress declared war on the Japanese on December 8, 1941 and on the European Axis of Germany and Italy three days later. Since that time there has not been a formal declaration of war by Congress. Does this mean that since the conclusion of WWII in 1945 the United States has not engaged in another war? The obvious answer is no. Since 1945, the United States has engaged in well known conflicts in Korea, Vietnam, Cambodia, Bosnia, the Persian Gulf, and Afghanistan. Some of the lesser known conflicts involving the United States Armed Forces include Bolivia, Columbia, Peru (in the War on Drugs implemented by George H.W. Bush), Panama, Haiti, Kosovo, the list continues. These conflicts have occurred under Harry Truman, Dwight Eisenhower, John Kennedy, Lyndon Johnson, Richard Nixon, Gerald Ford, Jimmy Carter, Ronald Reagan, George H.W. Bush, Bill Clinton, and George W. Bush—every president since WWII. ${ }^{1}$ What are the requirements for the United States Armed Forces to be dispatched to a foreign nation? This brings us back to the nation's origins- the Constitution.

In an effort to prevent a dictator from stripping the American people of their freedoms, the Founding Fathers created a government under the Constitution of the United States based on a separation of powers. The Philadelphia delegates had

\footnotetext{
${ }^{1}$ Edward Keynes, Undeclared War: Twilight Zone of Constitutional Power (University Park: Pennsylvania State University Press, 1982), 1.
} 
considerable debate over the power of the executive branch and in the end gave the position few defined powers. Under Article II, Section 2, the "President shall be Commander in Chief of the Army and Navy of the United States."2 The President was also given the power to make treaties (with the approval of the Senate) and to appoint ambassadors (to be confirmed by the Senate). They limited the President's role as Commander in Chief by giving Congress the sole authority to declare war, to raise money for it, and to end it by starving it of funds or by approving or rejecting treaties.

Political Journalist, Howard Fineman, argues that for a host of reasons, presidential leadership (or the lack of it) has come to dominate the discourse of American public life. One explanation he offers is that war, and rumors of war, and a national crisis that can be defined as war, stir yearning for a leader to master the situation-a commander in chief. ${ }^{3}$ But where did this yearning come from? Why does the nation feel compelled to turn to a single man in a time of need? Is that not what the Founding Fathers, the authors of the Constitution of the United States, wanted to guard against? In 1973, a united Congress ${ }^{4}$ felt the power relinquished to the President had gone too far. Although presidents had abused power in the past, including President Abraham Lincoln's suspension of habeas corpus in 1861 and again in $1862^{5}$, none had held such utter contempt for the restraints that kept this country free- "the restraints of reason,

\footnotetext{
2 "The Constitution of the United States," Article II, Section 2, Clause 1.

${ }^{3}$ Howard Fineman, The Thirteen American Arguments: Enduring Debates that Define and Inspire our Country (New York: Random House Publishing, 2008), 163.

${ }^{4}$ The War Powers Resolution passed in the Senate by a vote of 75-20 on October 10 and the House by a vote of 238-123 on October 12. President Nixon vetoed the resolution and a Congressional majority overrode the resolution 75-18 in the Senate and 284-135 in the House.

${ }^{5}$ In 1861, President Lincoln suspended civil law in territories where resistance to the North's military power would be dangerous. Again in 1862, President Lincoln suspended habeas corpus when copperhead democrats began criticizing the President's abuse of the Constitution. The second time he suspended civil law, it was throughout the nation and was done so with the intention of arresting all who discouraged enlistments or engaged in disloyal practices. In total, over 13,000 were arrested. This suspension was done by President Lincoln in an effort to preserve the Union during the American Civil War. In 1866, after the war concluded and the Union was preserved, habeas corpus was restored.
} 
decency, and above all, law." ${ }^{\prime 6}$ Disillusionment with presidential leadership in taking the United States into the costly and unsuccessful Vietnam conflict made Congress eager to rein in the executive's war-making authority. ${ }^{7}$

In response, the War Powers Resolution of 1973 was passed. The purpose of the resolution was "to fulfill the intent of the Framers of the Constitution of the United States and insure that the collective judgment of both the Congress and the President will apply to the introduction of the United States Armed Forces into hostilities, or into situations where imminent involvement in hostilities is clearly indicated by the circumstances, and to the continued use of such forces in hostilities or in such situations." ${ }^{.8}$ When the war in Vietnam set off a constitutional debate, Congressmen and historians alike attempted to determine what the Founders had in mind at the Constitutional Convention. While it is easy to ask what the Founders intended, the question is much more difficult to answer. ${ }^{9}$ The War Powers Resolution was created out of what the $93^{\text {rd }}$ Congress concluded was the Founders' original intent.

The most controversial components of the War Powers Resolution are found in Section Three and Five. The first, Section Three, requires that the President consult with Congress before introducing armed forces into hostilities, and after any such introduction, the President must continually consult with Congress until the forces are no longer engaged in hostilities or have been removed from such situations. The second important component, Section Five, requires that within sixty calendar days the President shall

\footnotetext{
${ }^{6}$ Anthony Lewis, "Evil and Malice Shared," New York Times, May 5, 1977; ProQuest Historical Newspapers, A27.

${ }^{7}$ Robert Dallek, Partners in Power: Nixon and Kissinger (New York: Harper Collins Publishers, 2007), 152.

${ }^{8}$ War Powers Resolution of 1973. $93^{\text {rd }}$ Congress, H. J. Res. 542. Section Two.

9 Michael Barnhart, Congress and the United States Foreign Policy: Controlling the Use of Force in the Nuclear Age (State University of New York Press: Albany, 1987), 127.
} 
terminate any use of United States Armed Forces unless Congress has 1) declared war or has enacted a specific authorization for such use of United States Armed Forces, 2) has extended by law such sixty-day period, or 3) is physically unable to meet as a result of an armed attack upon the United States. ${ }^{10}$ Section Five also states that at any time if the armed forces are engaged in hostilities outside the United States without a formal declaration of war or specific statutory authorization, such forces shall be removed by the President if the Congress so directs by concurrent resolution.

The War Powers Resolution has raised many questions about how Congress and the President work together with the armed forces. In the broadest sense, a Congress that had "generally rubber-stamped presidential initiatives since the Second World War now sought a position of codetermination in foreign policy making," by which it meant early and full consultation and even active participation in making decisions. ${ }^{11}$ Senator Jacob K. Javits, a sponsor of the War Powers Resolution, argued Congress had been too weak in the last 30 years. As he put it, "The price we have paid is too high; the death and maiming of tens of thousands of young in Vietnam, the Watergate scandals and the shadow of impeachment, which are expressions of an almost grotesque imbalance of power between Congress and the Presidency."12 President Nixon complained the War Powers Resolution represented an "unconstitutional and dangerous" denial of the President's proper role in the international sphere. ${ }^{13}$ President Ford and President Carter

\footnotetext{
${ }^{10}$ War Powers Resolution of 1973. Section Five.

${ }^{11}$ George Herring, From Colony to Superpower: U.S. Foreign Relations Since 1776 (New York: Oxford University Press, 2008), 814.

${ }^{12}$ Nathaniel Sheppard Jr., "Javits Will Propose Curbs on Powers of Presidency," New York Times, April 28, 1974; ProQuest Historical Newspapers, A1.

13 Melvin Small, The Presidency of Richard Nixon (Lawrence: University Press of Kansas, 1999), 245.
} 
claimed, as others have since, that consultation with Congress was evidence of their policies of cooperation—not that it was an attempt to comply with the resolution. ${ }^{14}$

Among the many concerns with the War Powers Resolution, there are constitutional questions that arise — can Congress really terminate presidential military action if a formal declaration of war is not made in sixty days? Does the resolution upset the balance of power in asserting that Congress has "unprecedented power" over the President in the conduct of foreign policy? If presidential administrations refuse to comply with the War Powers Resolution, is it really a valid resolution? Continuing that same argument, if the resolution is not sufficient in itself to accomplish its stated objective, need it be amended, or as some have argued, scrapped altogether? Another point to consider is whether the resolution's passage came out of Congress's fear of the Nixon Administration and what would become known as the "imperial presidency." 15 Although it is difficult to speculate whether a resolution like the War Powers Resolution would have passed in the absence of the presidency of Richard Nixon, it is evident that the growing power of the presidency since the Constitution's creation, particularly since the beginning of the twentieth century, in combination with the unconstitutional acts performed by President Nixon warranted action by the legislative branch.

This study will take a look at the respective powers under the Constitution of the President and Congress to enter into and conduct war. More specifically, this study will place a great emphasis on the War Powers Resolution of 1973 and the factors that

\footnotetext{
14 David M. Abshire, Ralph D. Nurnberger, The Growing Power of Congress (Washington D.C.: Sage Publications, 1981), 301.

15 The 'imperial presidency' is a term that became popular in the 1960s referencing the modern presidency. The best definition of the term comes from Arthur M. Schlesigner's book, The Imperial Presidency, which argues that the presidency throughout multiple administrations has acquired powers beyond the limits of the Constitution.
} 
motivated Congress to pass it. In collaboration with other political historians and constitutional scholars, this paper will argue that the conflict in Vietnam and the scandal of the Watergate break-in and subsequent cover-up under the administration of President Richard M. Nixon motivated Congress to swiftly pass the War Powers Resolution. Furthermore one can argue this was done without considering all of the potential shortcomings in an effort to quickly rein in the power of the growing executive branch at the cost of the legislative branch.

A large body of historiography exists on the constitutionality of congressional and presidential war powers. This area of interest has grown, especially since 1973. Although many works deal with the war powers, not all go into depth on the factors and motivations that led Congress in 1973 to pass the War Powers Resolution. Since I argue the Nixon Administration had such a large impact on the resolution's passage, additional resources outside of the war powers will be consulted to obtain an appropriate background on President Nixon. These resources include both primary and secondary accounts of Richard Nixon's presidency including, Melvin Small's The Presidency of Richard Nixon, Walter Isaacson's Kissinger, Robert Dallek's Partners in Power: Nixon and Kissinger, Stanley I. Kutler's Abuse of Power: The New Nixon Tapes, President Nixon's Memoirs, and Henry Kissinger's, Diplomacy, The White House Years, Years of Upheaval. 


\section{FOUNDERS DISCUSSION: WAR POWERS ORIGINAL INTENT AND THE BALANCE OF POWER}

In the course of American political history, Congress and the President often come to disagreements about the nature of their powers. Naturally, they return to the document that prescribes their powers to them-the Constitution. At different periods in history, each branch has efficiently used the Constitution to demonstrate why they have greater power in a particular aspect of law over the other branch. Since the last half of the twentieth century, no single power has been debated more than the war power.

Under the first governmental authority of the United States, the Articles of Confederation, Congress exercised both legislative and executive powers. "The United States in Congress assembled, shall have the sole and exclusive right and power of determining on peace and war." ${ }^{16}$ In 1787, however, this decade old document would be dramatically rewritten in Philadelphia, Pennsylvania by the elite American men of the eighteenth-century known as the Founders. The Philadelphia Convention drafted the Constitution of the United States of America which provided for a federal government with distinct branches, thereby necessitating some attention to the allocation of the warmaking power of the government. ${ }^{17}$

In 1789, the Founders assigned Congress very specific war powers. Under Article I, Section 8 of the Constitution, one can find how the Founders defined the Congressional war powers. Congress has the power to declare war, to raise and support armies, to

\footnotetext{
${ }^{16}$ Articles of Confederation, Articles VI, IX.

${ }^{17}$ Charles A. Lofgren, "Government from Reflection and Choice," Constitutional Essays on War, Foreign Relations, and Federalism ( New York: Oxford University Press, 1986), 6.
} 
provide and maintain a navy, to provide for calling forth the militia to execute the laws of the Union, and to provide for organizing, arming, and disciplining the militia. ${ }^{18}$

Just as Congress was assigned very specific roles, the President was too. Listed under Article II, Section 2, the President shall be Commander in Chief of the Army and Navy of the United States. The President also has the ability to make treaties and appoint ambassadors with the advice and consent of the Senate. ${ }^{19}$

Although there is extensive discussion of various topics released from the Convention notes, including taxes, and federal verses state authority, little is known about the original intent of the war powers. Among the 1,273 pages which contain the printed records of the convention, little more than one page explicitly considers allocation of the war-making power. ${ }^{20}$

In hindsight, it is surprising that this controversial issue provoked little discussion in Philadelphia. Some delegates preferred to give the power to the President; others feared granting such a power to one person. "Reflecting the spirit of compromise that marked the proceedings," James Madison urged assigning to the President as commander-in-chief the power to "repel sudden attacks" when Congress could not act but giving Congress the power to declare war. ${ }^{21}$

If the Founders identified the roles of the legislative and executive branches in regards to the power of war, why then is there an ongoing debate over two centuries later? The trouble with decidedly determining the victors of constitutional arguments lay in the ambiguous language the Founders chose. By taking a look at the debates and

\footnotetext{
18 "The Constitution of the United States," Article I, Section 8.

19 "The Constitution of the United States," Article II, Section 1.

20 Lofgren, 7.

21 Herring, 53.
} 
proceedings which accompanied the framing and ratification of the Constitutionparticularly by taking into account ideas common among Americans of the late eighteenth century as they interpreted the clauses in question, one can gain a better insight as to what the Founders meant when they assigned the war powers.

The one debate mentioned in the records of the Constitutional Convention about the allocation of the war-making power came from South Carolina delegates. Charles Pinckney opened the debate by arguing that the "legislature as a whole was too cumbersome a body to exercise [the war-making] power." ${ }^{, 22} \mathrm{He}$ felt the power should be vested in the Senate, which was smaller, and would therefore be more knowledgeable in the area of foreign affairs because of their treaty-making authority. Pierce Butler, also from South Carolina, took Pinckney's argument a step farther and wanted to vest the warmaking power in the President, but his proposal carried no recorded support. One other mention of altering the war-making power came from two men of Massachusetts, Madison and Elbridge Gerry. They moved to insert "declare," striking out "make" warleaving the Executive the power to repel sudden attacks. ${ }^{23}$ After some discussion the Madison-Gerry amendment was passed eight to one. ${ }^{24}$

Because there was such little recorded debate, Constitutional scholar Charles Lofgren and others turn to alternate indications of an original understanding of the warmaking power. Other aspects that have been examined by Lofgren and others include: deliberations from the Philadelphia Convention and the Constitution itself, the state assemblies debates over the ratification of the Constitution, some seventeenth and

\footnotetext{
${ }^{22}$ Lofgren, 7.

${ }^{23}$ Ibid.

${ }^{24}$ Only nine states cast votes on this issue because Massachusetts abstained, New York and New Jersey were not represented at this time, and Rhode Island never attended the Convention.
} 
eighteenth century trends in the theory and practice of war and reprisal, and English influences. As Lofgren points out, it is worth examining Constitutional deliberations because the Convention members were part of a broader community, so it is "likely that their fundamental assumptions were shared by other Americans." 25

For example, James Wilson of Pennsylvania did not believe the British Monarch was a proper guide for defining Executive Powers. He believed some of the monarch's powers should be allocated to the Legislative branch; this was to include war and peace. ${ }^{26}$ According to the records of the Convention, James Madison was in agreement with Wilson. This agreement among members, however, would not be explicitly laid out in the Constitution, and the war-making power was left ambiguous.

Three draft constitutions were prepared—one by Edmund Randolph of Virginia, one by James Wilson, and the copy submitted by the draft committee to the Convention. Each draft assigned the power "to make war" to the legislature. ${ }^{27}$ The lack of debate and the assignment of the war-making power to the Legislative Branch seem to indicate the Convention members were on the same page for the division of war powers.

Further indications of the Convention's understanding of the war-making provisions come from Alexander Hamilton. The plan of government that Hamilton presented to the Convention on June 18 demonstrates that despite his desire for a strong executive, he ultimately wanted the war-making ability to be given to the Senate-not the President. The President was to have "the direction of war when authorized or begun., 28

\footnotetext{
${ }^{25}$ Lofgren, 10.

${ }^{26}$ Lofgren, 11.

${ }^{27}$ Lofgren, 12.

${ }^{28}$ Lofgren, 13.
} 
Perhaps the most compelling argument that Lofgren puts forth is the argument about the state ratification debates. Five of the eleven states which ratified the Constitution before the new government commenced operation offered amendments to it, but of the seventy-seven amendments proposed, only one dealt with the power of Congress to declare war. ${ }^{29}$ The amendment, proposed by New York, was for two-thirds vote in each house of Congress for a declaration of war. This amendment was a means to protect state or regional interests - not to question the balance of the war-making powers between Congress and the President. During the state ratification process in Pennsylvania, James Wilson remarked,

This [new] system will not hurry us into war; it is calculated to guard against it. It will not be in the power of a single man, or a single body of men, to involve us in such distress for the important power of declaring war is vested in the legislature at large; this declaration must be made with the concurrence of the House of Representatives: From this circumstance we may draw a certain conclusion that nothing but our national interest can draw us into a war. ${ }^{30}$

Americans understood there was the possibility of a leader evolving into a despot as had happened so many times in Europe. They also feared a standing army because they thought it would be all too potent a tool—not for our security, but for dictatorial power. ${ }^{31}$ Ultimately, as Hamilton would point out, "it is better to hazard the abuse of confidence than to embarrass the government and endanger the public safety by impolitic restrictions on the legislative authority. ${ }^{\prime 32}$ He rejected the threat of war-making conspiracies between Congress and the President, which had been a reason offered by the Convention to prohibit a standing army. The decision of the Convention not to prohibit a standing

\footnotetext{
${ }^{29}$ Lofgren, 16.

${ }^{30}$ David Locke Hall, The Reagan Wars: A Constitutional Perspective on War Powers and the Presidency (San Francisco: Westview Press, 1991), 16.

${ }^{31}$ Fineman, 162.

${ }^{32}$ Hall, 20.
} 
army was evidence enough for legal scholar David Locke Hall to assert that this was evidence of the grant of the President's emergency war-making powers.

At the Philadelphia Convention there was much discussion over the handling of foreign affairs. Delegates originally agreed that the Senate should be primarily responsible for foreign affairs because an executive with too much power might replicate the monarchy from which they had just escaped. South Carolinian Charles Pinckney warned, it "would render the executive a monarchy of the worst kind, to wit an elected one." ${ }^{33}$ Ultimately such powers would be shared with the executive. Some felt the President could act as a check on the Senate and might serve "as the general Guardian of the national interest." 34

It has been argued by constitutional scholars that the Founders intentionally vested broad executive power in the presidency to be the prime agent in dealing with foreign affairs. This support comes from Hamilton's emphasis in Federalist 69, of the structural advantages of the presidency- unity, decision, secrecy, dispatch, stability of purpose, special sources of information, all made the President the more likely candidate to deal with foreign affairs.

Foreign policy specialist, Robert Turner, claims that the Founding Fathers intended to grant the President exclusive control over foreign affairs, subject only to certain very important but limited exceptions spelled out in the text of the Constitution. While Turner makes this assertion, Convention members were in disagreement. The power of 'Commander-in-Chief' merely made the President 'First General. ${ }^{35}$ In fact,

\footnotetext{
${ }^{33}$ Herring, 52 .

34 Ibid.

${ }^{35}$ Raoul Berger, “The Mayaguez Incident and the Constitution,” New York Times, May 23, 1975, ProQuest Historical Newspapers, 37
} 
according to the Convention records, James Wilson stated that the power to declare war was given to Congress to "guard against being hurried into war... so that no single man can involve us in such distress. ${ }^{, 36}$ The President's broad executive power over foreign affairs was not identical to that of the king of England, because certain very specific and important checks were included in the American system to guard against abuse. These differences are found in Federalist no. 69. In discussing the President's powers, Hamilton assures the people that,

The President will have only the occasional command of such part of the militia of the nation, as by legislative provision may be called into the actual service of the Union. The President's authority would be nominally the same with that of the King of Great Britain, but in substance much inferior to it. It would amount to nothing more than the supreme command and direction of the military and naval forces, as first general and admiral of the confederacy while that of the British king extends to the declaring of war, and to the raising and regulating of fleets and armies; all which by the constitution under consideration would appertain to the Legislature. $^{37}$

So despite the structural advantages of the Executive Branch pointed out by Alexander Hamilton in the beginning of Federalist no. 69, he reassures the reader that ultimately the Legislative Branch has possession of the final constitutional war powers.

The first major public debate over the division of war-making power between

Congress and the President occurred in mid-1793 following President George

Washington's proclamation of American neutrality in the war that broke out between England and France. ${ }^{38}$ This declaration of neutrality sparked debate among two members of the Philadelphia Convention-Pacificus and Helvidius, respectively Alexander Hamilton and James Madison.

\footnotetext{
${ }^{36}$ Ibid.

${ }^{37}$ Alexander Hamilton, Federalist Papers no. 69, 493.

${ }^{38}$ Lofgren, 3.
} 
This debate, less than a decade after the Constitution was written, has continued to the present day. Alexander Hamilton argued in a series of newspaper articles that since war-making was by nature an executive function, Congress could exercise only those aspects of it which the Constitution specifically grants the legislature. Conversely, James Madison argues that war-making was a legislative function and that any exceptions in favor of the executive must be strictly interpreted. ${ }^{39}$ Hamilton's argument, however, was not especially persuasive to fellow Federalists, let alone to the Republicans. ${ }^{40}$ James $^{4}$ Kent, representative of New York at the Philadelphia Convention concluded in 1795 that in the Untied States, "war only can be commenced by an act or resolution of Congress."41

The trouble with original intent, as with any constitutional question, is often that there is no record of the Founders explaining precisely what they meant. From their political and theoretical influences one may gain insight as to what the Founders were thinking, but it is difficult to claim that one has an exact understanding of controversial measures, especially the war powers. The Founders, faced with establishing a new form of government, drew on their collective knowledge and experience for the political and legal ideas and principles to devise not just a new order, but, as they conceived it, a new order for the ages. ${ }^{42}$ As Bailyn concludes, the Founders never doubted or questioned the fundamental importance of the legislative control of the power to prepare for and make war, as it was in the common law. They did not feel the need to explain it; it was assumed

\footnotetext{
${ }^{39}$ Lofgren, 4.

${ }^{40}$ Generally, the Federalists were regarded as advocates of a strong central government. If the Constitution did not explicitly say the government could not do something, then it had the authority to do it. Conversely, Republicans were more in favor of states rights and rights of the individual. At the time of ratification, Republicans believed that if the Constitution granted the federal government the authority specific authority, then it could not be done.

${ }^{41}$ Lofren, 36.

${ }^{42}$ Bernard Bailyn, The Ideological Origins of the American Revolution (Cambridge: Belknap Press of the Harvard University Press, 1967), 148.
} 
that future generations of Americans would know the history of political ideas and institutions, and would understand it. ${ }^{43}$

The American argument over leadership has become an important topic in the second half of the twentieth century because of something the Founders saw and feared, but could not imagine happening - an executive branch whose power has grown drastically since the creation of the Constitution. They thought they had carefully limited the President's role as commander-in-chief by giving Congress the sole authority to declare war, raise money for it, and to end it by starving it of funds or by approving a treaty. ${ }^{44}$ Although they implemented these tools, they have rarely been used as a check on the presidency's growing power.

In his discussion of the 'imperial presidency' Arthur Schlesinger, Jr. argues that the power of the executive has risen beyond the original intent of the Founders. He asserts that Alexander Hamilton, the Constitutional Convention's foremost proponent of executive energy, was even an advocate of the division of the war powers between Congress and the President. ${ }^{45}$ As evidence of his claim, Schlesinger cites Federalist 75, "The history of human conduct does not warrant that exalted opinion of human virtue which would make it wise to commit interests of so delicate and momentous a kind, as those which concern its intercourse with the rest of the world, to the sole disposal of... a President of the United States."46

By 1973, this is arguably exactly what the United States had become-a nation subject to the sole disposal of one man. In his follow up work, War and the American

\footnotetext{
${ }^{43}$ Barnhart, 30.

${ }^{44}$ Fineman, 163.

${ }^{45}$ Arthur M. Schlesinger, Jr., War and the American Presidency (New York: W. W. Norton \& Company, 2004), 47.

${ }^{46}$ Alexander Hamilton, Federalist Papers no. 75.
} 
Presidency, Schlesinger recaps that the American Constitution envisages a strong presidency within an equally strong system of accountability. When the constitutional balance is upset in favor of presidential power at the expense of presidential accountability, i.e. a weakened Congress, the presidency can become imperial. ${ }^{47}$ In the area of foreign affairs especially, the legislative branch lacks the confidence in their own information and judgment and are likely to be intimidated by the executive authority.

Returning to the early American presidencies, Schlesinger notes that "early Presidents did not hesitate to engage in what later generations called 'covert operations' against foreign states and to do so without congressional knowledge." ${ }^{48} \mathrm{He}$ calls this 'presidential adventurism,' something different from the imperial presidency. In the early republic, Presidents "deliberately selected venturesome agents, deliberately kept their missions secret, deliberately gave them vague instructions, deliberately failed either to approve or to disapprove their constitutionally questionable plans, and deliberately denied Congress the information to determine whether aggressive acts were authorized. ${ }^{49}$ These measures were taken because the Presidents wanted their men in the field to do things they knew lay beyond their constitutional right to command. "At no time did the executive claim 'inherent' power to initiate military actions." ${ }^{\text {50 }}$ The assertion of inherent powers in foreign affairs defines the imperial presidency. By 1973, President Richard Nixon would be the epitome of the imperial presidency, both in foreign and domestic affairs, and Congress would respond in an effort to even the political

\footnotetext{
${ }^{47}$ Schlesinger, 45.

${ }^{48}$ Ibid, 49.

${ }^{49}$ Ibid, 49-50.

${ }^{50}$ Sofaer, 61 .
} 
balance. Perhaps the best example of President Nixon's imperial presidency in foreign affairs is his role in the Vietnam War. 


\section{VIETNAM}

George Washington's Farewell Address in 1783 set forth a precedent in American foreign policy. He cautioned future leaders to adopt a policy of non-alignment, "It is our true policy to steer clear of permanent alliances with any portion of the foreign world..." ${ }^{51}$ A President in the early part of the twentieth century would question this policy. President Woodrow Wilson's concept of foreign policy was much different from his predecessors and would alter the role of the Untied States of America in the rest of the world indefinitely. The Wilsonian approach to foreign policy permitted that no distinction be made among the relative importance of various countries. America, under this policy, was obliged to fight for what was right, regardless of local circumstances, and independent of geopolitics. $^{52}$

With this mindset, Presidents after Wilson proclaimed that any involvement in foreign policy was not met with the selfish interests of the United States, but rather the goal of any such involvement was that of peace and progress. President Harry Truman's inaugural address January 20, 1949 committed the United States to the objective of a world in which "all nations and peoples are free to govern themselves as they see fit...",53 After Truman, Dwight Eisenhower took America's foreign policy one step furtherAmerica's involvement in foreign affairs was an extension of America's moral responsibility not just a balancing of risks and rewards.

\footnotetext{
${ }^{51}$ Washington, George, George Washington's Farewell Address (Bedford: Appleewood Books, 1999).

${ }^{52}$ Henry Kissinger, Diplomacy (New York: Simon \& Schuster Paperbacks, 1994), 621.

${ }^{53}$ Kissinger, 622.
} 
In his only inaugural address, President John Kennedy followed similar paths taken by his predecessors in regards to foreign policy. He stated, "Let every nation know, whether it wishes us well or ill, that we shall pay any price, bear any burden, meet any hardship, support any friend, oppose any foe to assure the survival and the success of liberty." ${ }^{54}$ In kind, Lyndon B. Johnson's inaugural made a promise to the world that no stranger was beyond hope. "If American lives must end, and American treasure be spilled, in countries that we barely know, then that is the price that change has demanded of conviction and of our enduring covenant." ${ }^{, 55}$ All the Presidents since Woodrow Wilson bought into the idea of America as a protector of freedom for the world at large, taking that position a step further with each passing administration.

Despite America's changing involvement in foreign policy in the twentieth century, it is still surprising that America entered Indochina ${ }^{56}$ in the 1950s. Indochina was among the last remaining colonies held by France and America held a tradition of anticolonialism. ${ }^{57}$ President Truman decided, however, that the security of the free world required Indochina to be kept out of communist hands—-which meant supporting the French struggle in that location. ${ }^{58}$ Truman's legacy to his successor, Eisenhower, was an

\footnotetext{
${ }^{54}$ Ibid.

${ }_{55}^{55}$ Ibid, 623.

${ }^{56}$ When the United States became involved in Southeast Asia in assistance of France, the region was called Indochina. Indochina consists of Vietnam, Laos, and Cambodia — all regions that would be heavily impacted by the Vietnam War. In the United States' early involvement in the region, it is consistently referenced as Indochina, although later the regions would be recognized as their individual countries.

${ }^{57}$ Not all historians are in agreement with America's alleged anticolonialism. The annexation of Hawai'i, and former Spanish colonies after the Spanish-American war, are perhaps the best known examples that complicate this picture.

${ }^{58}$ After victory, America intended to reconcile its strategic and anticolonial convictions by pressing for independence in Indochina.
} 
annual military-assistance program to Indochina of some $\$ 200$ million and a strategic theory in search of policy. ${ }^{59}$

President Truman sent a few American soldiers to Vietnam, but it was not until the Kennedy Administration that the United States really started to take an active role in Southeast Asia. Upon President Kennedy's assassination, the United States had committed 16,000 American troops to Vietnam. ${ }^{60}$ On August 2, 1964, North Vietnamese patrol boats may have attacked the Maddox, an American destroyer in the Gulf of Tonkin. A second incident, involving the Turner Joy, was reported in the Gulf of Tonkin two days later. As a result of the information provided to its members, Congress passed the Southeast Asia Resolution (more commonly known as the Gulf of Tonkin Resolution), which on its face gave the President broad powers to defend against aggression in the area. $^{61}$ By the time of President Nixon's inauguration on January 20, 1969, the United States had committed 536,000 United States Armed Forces to the Vietnam War. When the United States' involvement was finished, the American war in Indochina had become the longest in our history, the second most expensive monetarily, and the fourth most costly in American lives. ${ }^{62}$

Although the Gulf of Tonkin Resolution was seen as Congressional authorization to wage war in Vietnam, its repeal did not carry the opposite effect- that the war in Vietnam was no longer to be waged. Passed on January 12, 1971, Congress hoped that repealing the resolution would mean an end to the war was in sight. ${ }^{63}$ This resolution

\footnotetext{
${ }^{59}$ Kissinger, 628.

${ }^{60}$ John Hart Ely, War and Responsibility: Constitutional Lessons of Vietnam and its Aftermath (Princeton: Princeton University Press, 1993), 13.

${ }^{61}$ Ibid, 13.

${ }^{62}$ Ely, 13.

${ }^{63}$ Ibid, 32.
} 
repealed the Gulf of Tonkin Resolution ${ }^{64}$ as well as provided an amendment to a foreign military sales bill sharply restricting future operations in Cambodia, including the dispatching of troops, or the use of advisors or air forces in support of Cambodia's army. ${ }^{65}$ Robert Dallek, esteemed historian specializing in the American Presidency, notes that for the moment, the Senate measures were only a threat—but they did signal the extent to which Nixon and Kissinger might be limited in what they could do in future engagements.

To the dismay of Congress, President Nixon asserted that the Tonkin Resolution was not essential to the President's authority. American ground forces were pulled from Cambodia on June 30, 1970. The bombing of Cambodia continued so long as our forces were still placed in Vietnam, rationalized on the theory that it was protecting our troops and otherwise helping us defend South Vietnam. ${ }^{66}$ However, on January 27, 1973 the Paris cease-fire agreements had been signed; on March 29 the last American troops left Vietnam; and on April 1 our last known prisoners of war were released. Despite the cease-fire and the withdrawal of American armed forces, the bombing of Cambodia continued until August 14, 1973.

In addition to the continued bombing of Cambodia, (even after the last known prisoner of war was released) the United States Congress and the American people became aware in 1973 that President Nixon had authorized the secret bombing of Cambodia beginning in 1969. When Major Knight asked his commanding officer why he was being told to falsify records of the exposed cover-up, he was told that "the purpose

\footnotetext{
${ }^{64}$ The Gulf of Tonkin Resolution was a joint resolution passed by Congress on August 7, 1964. The resolution has great historical significance because it gave President Johnson authorization, without a formal declaration of war, for the use of military force in Southeast Asia.

${ }^{65}$ Dallek, 200.

${ }^{66}$ Ely, 34.
} 
was to hide these raids." Knight questioned who they were to be hidden from; the reply he received was "Well, I guess the Foreign Relations Committee."67 Chair of the Joint Chiefs Earle Wheeler testified that President Nixon ordered him, no fewer than six times, not to disclose the Cambodian bombing to "any member of Congress." In his memoirs, President Nixon cites multiple reasons for his secrecy,

We anticipated that as long as the bombing remained secret, the North Vietnamese would find it difficult to protest since they were officially denying that they had any troops in Cambodia. Another reason for secrecy was the problem of domestic antiwar protest. My administration was only two months old, and I wanted to provoke as little public outcry as possible at the outset. ${ }^{68}$

President Nixon would continue to justify his decision of secrecy in his Memoirs by admonishing that Richard Russell and John Stennis, the Chairman and the ranking member of the Senate Armed Services Committee both believed, despite increasing doubts about the war, that the bombings were the right decision, and that they would back the President up, even if the bombings would later become public. ${ }^{69}$

Air Force Major Hal Knight blew the whistle on the secret bombings mid-1973. Congress and the American people were outraged by the lies. The Pentagon not only submitted to the Senate Armed Services Committee falsified documents that did not list any B-52 raids on Cambodia at all during the thirteen months when they were actually taking place almost nightly, but also flatly assured the Committee there had been "no B52 bombing in Cambodia of any kind during the entire year of 1969."70 Operation Breakfast, as the secret bombing was called, continued. During that time 108,823 tons of bombs were dropped on the six board-area base camps. The bombing of Cambodia was

\footnotetext{
${ }^{67}$ Ely, 102.

${ }^{68}$ Richard Nixon, The Memoirs of Richard Nixon: Volume One (New York: Warner Books Inc., 1978), 472.

${ }^{69}$ Ibid, 472.

${ }^{70}$ Walter Isaacson, Kissinger: A Biography (New York: Simon \& Schuster Paperbacks, 1992), 176-177.
} 
President Nixon and Secretary of State Kissinger's means of waging their own war-a war they knew Congress and the American people would not support. ${ }^{71}$

In the aftermath of the quagmire of the Vietnam War that lasted nearly a decade from $1964-1973^{72}$, Americans were ready for a change in how the United States entered war. Much of the blame for the proceedings of the war-appropriately or not, went to President Richard Nixon. Although the war arguably began under the Eisenhower and Kennedy administrations, and was escalated under President Lyndon Johnson, President Nixon inherited (and escalated) the war and the prior administrations troubles. After President Johnson committed over five hundred thousand American troops it was clear that Vietnam was rapidly becoming, according to historian Robert Dallek, the greatest foreign policy disaster in the country's history. ${ }^{73}$ After travelling to Vietnam for two weeks in the spring of 1965, Henry Kissinger reported to Henry Cabot Lodge, the U.S. Ambassador in Saigon,

We had involved ourselves in a war which we knew neither how to win or how to conclude... We were engaged in a bombing campaign powerful enough to mobilize world opinion against us but too halfhearted and gradual to be decisive... No one could really explain to me how even on the most favorable assumptions about the war in Vietnam the war was going to end. ${ }^{74}$

The war's statistics would speak for themselves—58,209 killed in action; 303,635 wounded in action; 1,948 missing in action. Although Secretary of State Kissinger made his statement upon his first visit in 1965, it could be argued that even in the spring of

\footnotetext{
71 Anthony Lewis, "Evil and Malice Shared."

${ }^{72}$ This date varies based upon the source you are consulting. Most frequently in the research I came across, it was listed as beginning in 1964 because this is when the Gulf of Tonkin Resolution was passed.

Although the start date of the war is listed at 1964, the United States had been involved in some fashion in the Indochina conflict since as early as 1950 .

73 Robert Dallek, Partners in Power: Nixon and Kissinger (New York: Harper Collins Publishers, 2007), 31.

${ }^{74}$ Dallek, 57.
} 
1973 his words remained true. Among the troubles Nixon would later face, Cambodia did not disappear. Although President Nixon cannot take the blame for the entire conflict in Southeast Asia, as John Hart Ely points out, the secret bombing of Cambodia was an offense consummated by one and only one President. ${ }^{75}$ The secret bombing of Cambodia almost made it into the final version of the Articles of Impeachment. Congressman John Conyers introduced an article charging that President Nixon had violated his constitutional oath of office when he authorized the concealment of facts of the operations in Cambodia in "derogation of the power of the Congress to declare war, to make appropriations, and to raise and support armies..."76 Vietnam and the troubles associated with it would leave a permanent scar on not only President Nixon's record, but on the war powers of future Presidents as well. The Vietnam experience buried the notion of Presidential infallibility on foreign affairs.

\footnotetext{
${ }^{75}$ Ely, 103.

${ }^{76}$ Ibid.
} 


\section{WATERGATE}

When it was thought that Congress and the American public's frustrations with the Nixon Administration could not get any worse, scandal erupted in the White House. The Vietnam War was no longer the most troubling policy the administration had to overcome. The Watergate investigation began after a break-in to the Democratic National Committee headquarters on June 17, 1972. Seven men were indicted in association with the break in for burglary, conspiracy, and violation of federal wiretapping laws. Four Cubans, Bernard Barker, Virgilio Gonzalez, Eugenio Martinez, Frank Sturgis, and E. Howard Hunt pleaded guilty; a jury later found Gordon Liddy and James McCord guilty. ${ }^{77}$ Once Nixon discovered the connection between the burglars, $\mathrm{CREEP}^{78}$, and the White House, he along with John Dean, H. R. Haldeman, and John Ehrlichman began to cover up the affair. The cover-up began as early as June 20, 1972. The eighteen and a half minute taped conversation between the aforementioned men included a strategy spanning the course of a couple of weeks to keep the White House out of the affair, limit the investigation to the simple burglary, and pay money to assist those arrested with their legal defenses and to ensure their silence. ${ }^{79}$ Unfortunately for the White House, the cover-up was spoiled. The FBI traced some of the money the burglars carried to a Miami bank-one link in a scheme in a vast plot to launder funds donated to CREEP through Mexican banks. In an effort to derail the FBI, the "smoking-gun" tape revealed the plan that involved CIA director Vernon Walters calling FBI chief Patrick

\footnotetext{
${ }^{77}$ Melvin Small, The Presidency of Richard Nixon (Lawrence: University Press of Kansas, 1999), 273.

${ }^{78}$ CREEP, also abbreviated CRP, was the Committee to Reelect the President, a Nixon White House fundraising organization.

${ }^{79}$ Small, 276.
} 
Gray to say "stay the hell out of this... this is ah, business here we don't want you to go any further on it." ${ }^{, 80}$ This fraudulent use of national security was Nixon's first significant involvement in the illegal measures taken to curtail the Watergate investigation.

The second illegal activity the President engaged in was an attempt to silence the burglars by paying them off or even promising them clemency. Through CREEP, over the course of a couple of months, Maurice Stans (CREEP's finance chief), Fred C. LaRue (another CREEP official), and Haldeman provided over \$350,000 to Herbert Kalmbach (Deputy Finance Chairman of CREEP and personal attorney for Nixon). Most of the money was given to E. Howard Hunt's wife, Dorothy, to pay for bail, lawyers' fees, and 'income replacement' for the seven men arrested on June $17 .{ }^{81}$

Just prior to the seven burglars' sentencing on March 19, 1973, James McCord revealed to presiding judge John J. Sirica that "political pressure was applied to the defendants to plead guilty and remain silent." Furthermore, he also asserted that witnesses had perjured themselves so that "others in the Watergate operation were not identified" during the trial in January. ${ }^{82}$ Less than two weeks later, McCord would reveal more damning evidence. On March 30, McCord revealed to the Ervin Senate committee that Liddy and Hunt had told him that Magruder, Mitchell, Dean, Haldeman, Colson, and others approved of or knew about the break-in.

In response to the break-in, the Senate voted seventy to zero to establish a select committee of four Democrats and three Republicans to investigate Watergate. ${ }^{83}$ From May to August of 1973, key administrative officials had to give testimony at televised

\footnotetext{
${ }^{80}$ Stanley I. Kutler, ed., Abuse of Power: The New Nixon Tapes (New York: Free Press, 1997), 67.

${ }^{81}$ Small, 278.

${ }^{82}$ Ibid, 281.

${ }^{83}$ Ibid, 279.
} 
hearings before the Senate Committee. Among those to testify would be key witness White House Counsel John Dean. In light of McCord revealing his involvement, on March 30, Dean's attorney informed Watergate prosecutors that his client was prepared to tell them what he knew of the affair, including "the Ellsberg break-in, Hunt's safe, and Ehrichman's, Haldeman's, and Nixon's involvement in the hush money and cover-up schemes." ${ }^{.84}$ Dean feared Nixon and his chief aides would make him the scapegoat, and began to arrange the best deal possible for himself. Just a couple of weeks after McCord's confession, Nixon understood the Watergate investigation was approaching the White House. Haldeman and Ehrlichman would be closely linked to the scandals by their colleagues. In a preemptive strike, Nixon announced to a television audience that he was accepting the resignations of Haldeman and Ehrlichman, and Dean had resigned already.

After the hearings began, the President issued a statement to the American people. On May 22, 1973, President Nixon asserted, "I took no part in, nor was I aware of, any subsequent efforts that may have been made to cover up Watergate. ${ }^{„ 85}$ The President also denied having prior knowledge of the break-in, offering anyone clemency, raising hush money, trying to implicate the CIA, authorizing his aides to commit illegal acts, or knowing anything about the Ellsberg break-in until recently. Haig, one of the President's staunchest defenders, later wrote that of the seven denials, six were lies. ${ }^{86}$ In his testimony on June 25, Dean explained that he had been personally in charge of the Watergate cover-up and that he had attended the key White House meetings on June 23, 1972 and March 21, 1973. To support his testimony, he wrote an extensive statement and had taken a plethora of documents from the White House. This revelation placed Nixon

\footnotetext{
${ }^{84}$ Small, 282.

${ }^{85} \mathrm{Ibid}, 283$.

${ }^{86}$ Ibid, 284.
} 
at the epicenter of the conspiracy. During the testimony, Republican Senator Howard Baker of Tennessee asked the question, "What did the President know, and when did he know it?"87 For the first time, President Nixon's role in the Watergate scandal was officially questioned.

Along with the investigations, the press also contributed to President Nixon's declining approval rating. During the Spring and Summer of 1973, polls showed that the presidential approval rating had dropped to 31 percent. ${ }^{88}$ Carl Bernstein and Bob Woodward, reporters from the Washington Post, delivered the stunning revelations and missing pieces of the puzzle that led to President Nixon's downfall. After Woodward's last meeting with his anonymous White House source, Deep Throat, later revealed to be Associate Director of the FBI W. Mark Felt ${ }^{89}$, it was clear that the Watergate cover up went all the way to the President. ${ }^{90}$ Although the revelation of the President's involvement would not come until the spring of 1974, the President's actions leading up to his involvement served only to further harm the image of the Executive Office.

Under the duress of the Watergate investigation, President Nixon made several poor decisions. The "Saturday Night Massacre" on October 20, 1973 is one example of President Nixon's folly during Watergate. Archibald Cox was hired by Attorney General Elliot Richardson to investigate the Watergate scandal independent of the Justice

\footnotetext{
${ }^{87}$ Small, 284-285.

${ }^{88}$ Ibid, 286.

${ }^{89}$ The name Deep Throat was a pseudonym given by Bob Woodward to his secret informant during the Watergate scandal. The concealed identity was a great political controversy of the later part of the twentieth century. Deep Throat's identity was only known to seven people-Associate Director of the F.B.I. W. Mark Felt, Carl Bernstein, Bob Woodward, Washington Post editor Benjamin Bradlee, and his successor Leonard Downie, Jr., and Assistant Attorney General J. Stanley Pottinger. The identity of Deep Throat was highly speculated but was not officially revealed to be Mark Felt until an article was published in the July 2005 issue of Vanity Fair.

${ }^{90}$ Carl Bernstein, Bob Woodward, All the President's Men (New York: Simon \& Schuster, Inc., 1974), 318.
} 
Department. During the investigation Deputy Assistant to President Nixon, Alexander Butterfield, was questioned. During his questioning on July 13, 1973 Butterfield made a startling revelation before the committee. In this interview he revealed that so long as the President was in attendance, everything in the White House was taped. ${ }^{91}$ Watergate Prosecutor, Archibald Cox joined the Senate committee and subpoenaed the seven tapes of conversation with President Nixon and John Dean in an effort to determine who was telling the truth. Nixon met with his advisors to determine what to do with the tapesburn them or keep them? Ultimately Nixon decided not to destroy the tapes. The President had hoped that the courts would rule in his favor and the tapes would not be required to be released. Much to his surprise, the court ruled in favor of the Senate Committee.

On October 12 the U.S. Court of Appeals ruled that the prosecutors and the President needed to work out a deal so that national security was not compromised and the tapes would be released. President Nixon resisted the court-ordered release of his tapes citing the Constitutional principle of executive privilege. Nixon urged Attorney General Richardson to order Cox to drop the subpoena. Richardson refused to carry out Nixon's order and offered his resignation. Deputy attorney general William Ruckelshaus also refused to execute Nixon's order and resigned as well. Robert Burk the Solicitor General then fired Cox. The event was named by the press the "Saturday Night Massacre." To Congress, the press, and the public, the event resembled the actions of a

\footnotetext{
${ }^{91}$ Dallek, 517.
} 
dictator with no genuine regard for the rule of law. ${ }^{92}$ The tapes revealed to the nation that “in private its President was a profane and nasty fellow who behaved in a manner unbecoming of his office."93 The tapes revealed ultimately that President Nixon had committed a number of crimes.

In his book, It Didn't Start with Watergate, Victor Lasky wrote in defense of the Nixon Administration that other Presidents committed many of the same crimes and misdemeanors that Nixon committed, including illegal wiretapping and using federal agencies for political intelligence. What differentiated the Nixon administration was the fact that some Presidents participated in illegal activities much of the time, and others did almost all of them on occasion, but none of them committed all the illegal acts that constituted Watergate all the time..$^{94}$

Disillusionment with presidential leadership in taking the United States into the costly and unsuccessful Vietnam made Congress eager to reign in the executive's warmaking authority. ${ }^{95}$ The trouble that President Nixon faced with foreign policy was compounded with a domestic scandal on a scale that no other President had faced before. Because of Watergate, "a President fresh from the second largest electoral victory in our history was unseated in a revolution that his own actions had triggered and his conduct could not quell." "96 To Nixon, the break-in, the cover-up, and the hard-ball politics were

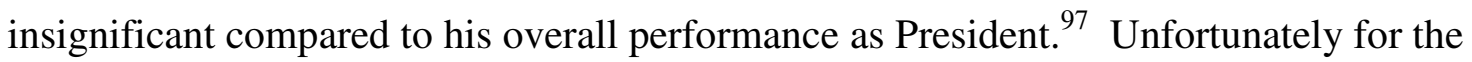
President, Congress and the American public did not agree. As a result of the Saturday

\footnotetext{
92 Ibid, 518.

${ }^{93}$ Small, 286

${ }^{94}$ Ibid, 273.

95 Dallek, 518.

${ }^{96}$ Henry Kissinger, Years of Upheaval (Boston: Little Brown, 1982), 401.

${ }^{97}$ Small, 274.
} 
Night Massacre and the scandal surrounding Watergate, a Gallup poll in late October revealed the President's approval rating had dropped 17 percent to a 27 percent approval rating. ${ }^{98}$ In response, in the fall of 1973 , Congress produced a piece of legislation that made an effort to reestablish the constitutional balance of power between the executive and legislative branches.

${ }^{98}$ Ibid, 290. 


\section{THE WAR POWERS RESOLUTION}

The War Powers Resolution was passed on November 7, 1973. This resolution represented an attempt by Congress to do something which, as Undersecretary of State George Ball put it, the Founding Fathers thought they could not do—namely to spell out the dividing line between the constitutional power of Congress to declare war and the constitutional power of the President as commander-in-chief. ${ }^{99}$

Abraham Sofaer argues that the Founders expected the branches to battle each other to acquire and defend power. To prevent the supremacy of one branch over any other in these battles, powers were mixed; each branch was granted important powers over the same area of activity. ${ }^{100}$ If what Sofaer asserts is true, the War Powers Resolution is an attempt to restore the political balance.

The resolution would have to be passed over President Richard Nixon's veto, a Congressional achievement, but not what the principal sponsor of the resolution, Republican Senator from New York, Jacob Javits, had hoped for. Senator Javits was anticipating that Congress would work out a "methodology" for joint presidentialcongressional action in sending American troops into combat. ${ }^{101}$ He had hoped that President Nixon would sign it, and the resulting law would then represent a pact between Congress and the President for making the Constitution work in what is generally admitted to be a gray area.

\footnotetext{
${ }^{99}$ Pat M. Holt, The War Powers Resolution: The Role of Congress in the U.S. Armed Intervention. (Washington D.C.: American Enterprise Institute for Public Policy Research, 1978), 1.

${ }^{100}$ Abraham D. Sofaer, War, Foreign Affairs, and Constitutional Power: The Origins. (Cambridge:

Ballinger Publishing Company, 1976), 60.

${ }^{101}$ Holt, 1.
} 
The veto had compromised the promise that Congress felt the War Powers Resolution carried. President Nixon's veto meant that the President would not accept any part of the resolution, and left the result somewhat cloudier than it would have been otherwise. ${ }^{102}$ To understand what President Nixon found unconstitutional, one must take a closer look at what the War Powers Resolution contained.

The War Powers Resolution, formally known as Public Law 93-148, was composed of ten sections, some bearing more constitutional importance than others. The first section states that PL 93-148 may be cited as the War Powers Resolution. The second section contains the purpose and policy of the resolution-

to fulfill the intent of the framers of the Constitution of the United States and insure that the collective judgment of both the Congress and the President will apply to the introduction of United States Armed Forces into hostilities, or into situations where imminent involvement in hostilities is clearly indicated by the circumstances, and to the continued use of such forces in hostilities or in such situations. $^{103}$

Furthermore, the section lays out the constitutional authority of Congress under Article 1, Section 8, and that of the President — that he may only introduce the armed forces into hostilities pursuant to 1) a declaration of war, 2) specific statutory authorization, or 3) a national emergency created by attack upon the United States, its territories or possessions, or its armed forces.

Section Three of the War Powers Resolution introduces the concept of consultation among the Executive and Legislative branches: "The President in every possible instance shall consult with Congress before introducing United States Armed Forces into hostilities... and after every such introduction shall consult regularly with the

\footnotetext{
102 Ibid, 2.

103 “War Powers Resolution of 1973,” 93 ${ }^{\text {rd }}$ Congress, H. J. Res. 542. November 7, 1973.
} 
Congress until United States Armed Forces are no longer engaged in hostilities or have been removed from such situations." 104

Reporting is the subject of Section Four. It holds that in the absence of a declaration of war, in any circumstance that United States Armed Forces are committed to hostilities, a circumstance where combat is imminent; when troops are put into the territory, airspace, or waters of a foreign nation while equipped for combat; or when troops are introduced in numbers that substantially enlarge already existing United States Armed Forces equipped for combat in a foreign nation, the President shall submit within 48 hours to the Speaker of the House of Representatives and to the President pro tempore of the Senate a report setting forth-1) the circumstances necessitating the introduction of United States Armed Forces, 2) the constitutional and legislative authority under which such introduction took place, and 3) the estimated scope and duration of the hostilities or involvement. ${ }^{105}$ After the initial report, the President must report to the Congress periodically on the status of such hostilities or situation as well as on the scope and duration of the hostilities. This reporting must be done no less than once every six months.

Section Five, about Congressional Action, goes more in depth than the prior sections. This section holds that within sixty calendar days after a report is submitted or is required to be submitted pursuant to Section Four, whichever is earlier, the President shall terminate any use of United States Armed Forces with respect to which such report was submitted —unless Congress has 1) declared war or enacted s specific authorization for such use of United States Armed Forces, 2) has extended by law such sixty-day

\footnotetext{
104 "War Powers Resolution of 1973," Section 3.

105 "War Powers Resolution of 1973," Section 4.
} 
period, or 3) is physically unable to meet as a result of an armed attack upon the United States. ${ }^{106}$ And finally, if at any point in time that the United States Armed Forces are engaged in hostilities outside the territory of the United States without a declaration of war or specific statutory authorization, such forces shall be removed by the President if the Congress so directs by concurrent resolution.

The subject of Section Six is Congressional priority procedures for a joint resolution or bill. It holds that any joint resolution or bill introduced as a result of Section Five shall be referred to the Committee on Foreign Affairs of the House of Representatives, or the Committee on Foreign Relations of the Senate. It sets a time frame for the House and the Senate to each vote on the joint resolution or bill and to do so before the sixty day time limit in Section Five is met. ${ }^{107}$ In the case of disagreement between the two Houses, conferees shall be appointed and the committee of conference shall make and file a report. The next section follows the exact same line of Section Six. Section Seven sets priority procedures for a concurrent resolution.

The interpretation of joint resolution is provided in Section Eight. It provides further definition of the term "introduction of United States Armed Forces"- "the assignment of members of such armed forces to command, coordinate, participate in the movement of, or accompany the regular or irregular military forces of any foreign country or government when such military forces are engaged, or there exists an imminent threat that such forces will become engaged, in hostilities."108 Furthermore, for clarification purposes, Section Eight asserts that nothing in the joint resolution is intended to alter the constitutional authority of the Congress or the President, or the provisions of

\footnotetext{
106 “War Powers Resolution of 1973," Section 5.

107 "War Powers Resolution of 1973," Section 6.

108 “War Powers Resolution of 1973," Section 8.
} 
existing treaties. The section continues that nothing shall be construed as granting any authority to the President with respect to the United States Armed Forces into hostilities or into situations wherein involvement in hostilities is clearly indicated by circumstances which authority he would not have in the absence of the joint resolution.

The separability clause is contained in Section Nine. It asserts that should any part of the War Powers Resolution be determined invalid, the remainder of the joint resolution and the application of such provision to any other person or circumstance shall not be affected. ${ }^{109}$ The final section, Section Ten, holds that the joint resolution shall take effect on the date of its enactment.

Much of what is contained in the War Powers Resolution was as Senator Javits put it, an attempt to maintain status quo-uphold the Constitution. ${ }^{110}$ Taken at face value, Congress is being very assertive in setting time requirements and placing conditions on the ability of the United States to commit armed forces. Although the language is both eloquent and demanding, one cannot help but notice a hint of desperation and frustration. The War Powers Resolution was not Congress's first attempt at revisiting the division of power between the President and the Legislative Branch, but it was the most dramatic.

The precursor to the War Powers Resolution was a Senate resolution-the National Commitments Resolution. Passed on June 25, 1969, the Senate resolution contained the definition of United States Armed Forces commitment. The resolution did not have the force of law, but it was the "sense of the Senate" that the President never

\footnotetext{
109 "War Powers Resolution of 1973," Section 9.

${ }^{110}$ Holt, 7.
} 
again commits armed forces overseas without the consent of Congress. ${ }^{111}$ In 1969, it was evident that Congress—-both liberals and conservatives, were not going to accept unilateral presidential initiatives in foreign affairs. A Time Magazine articled written in response to the National Commitments Resolution concluded that "As a result of Viet Nam, many in Congress are distrustful of any President's wisdom and determined to deny him even the military means, let alone the authority, to intervene unilaterally. One thing is certain: Richard Nixon will be watched more closely by Congress than have been any of his predecessors of the past few decades." 112 The author of this article had exceptional foresight.

The U.S. incursion in Cambodia in May 1970 triggered multiple bills on war powers in both the House and the Senate. The Senate bill at the time, the Senate War Powers Bill of 1972, was an example of the legislative branch attempting to reclaim the balance of power between the President and Congress. It provided that Congress by act or joint resolution could terminate the use of United States Armed Forces by the President within thirty days of committing troops unless Congress authorized their continued use. ${ }^{113}$ The House would not pass the Senate bill. The House bill that was then proposed just urged the President to consult with Congress before sending Americans into armed conflict and eliminated the Senate requirements.

Because of the great differences in the House and Senate bills, agreement was never reached and nothing came of the bills. Frustrations over the ineffectiveness of Congress were not only felt among members of the Congress. A professor of political

\footnotetext{
111 “Nation: The Commitments Resolution,” Time. July 4, 1969.

112 Ibid.

${ }^{113}$ Ann Van Wynen Thomas, The War-Making Power of the President: Constitutional and International Law Aspects (SMU Press: Dallas, 1982), 126.
} 
science from Davidson College, William E. Jackson, Jr., argued in a 1972 letter to the editor of the New York Times, "the Senate appears impotent in the face of executive domination that the House is an instrument of Presidential will. Despite constitutional provisions to the contrary, the President decides when the country goes to war, how the war is prosecuted, and whether it is extended to other countries." 114

In 1973, the committees in both the House and the Senate started afresh. ${ }^{115}$ What is most notable about the resurgence in Congressional war powers bills was the passion of the House. The House bills traditionally lagged behind the Senate bills in asserting Congressional authority—in 1973 this was not the case. The House bill, “...provided for the withdrawal of American forces from hostilities within 120 days unless Congress approved their involvement." withdraw from both hostilities and foreign deployments by a concurrent resolution. The final catch to the House bill that was not found in the Senate bill, was that it applied to current hostilities—namely to those in Southeast Asia.

Although the conferees would eliminate the more extreme measures of the House bill to pass it through both the Senate and the House, it was a clear indication of where not only the Legislative Branch was on the separation of powers issue, but also where the rest of the nation stood. As representatives of their constituents, Congress overwhelmingly passed the conference report-the Senate by a vote of 75-20 on October 10 and the House by a vote of $238-123$ on October $12 .{ }^{117}$

\footnotetext{
${ }^{114}$ William E. Jackson Jr., “A Senate Blockade Could Stop the War,” New York Times, June 20, 1972, ProQuest Historical Newspapers, 38.

${ }^{115}$ Holt, 5.

${ }_{116}^{16}$ Ibid.

${ }^{117}$ Ibid, 7 .
} 
Less than two weeks after the passage of the War Powers Resolution, President Nixon invoked his executive veto power on October 24. In response to his veto, President Nixon stated, "the restrictions which this resolution would impose upon the authority of the President are both unconstitutional and dangerous to the best interests of our Nation." Furthermore, Nixon argued that the resolution "would have vastly complicated or even made impossible" the American response to the Berlin crisis of 1961, the Cuban missile crisis of 1962, the Congo rescue operation of 1964, and the Jordanian crisis of 1970. It would,

undercut the ability of the United States to act as an effective influence for peace. For example, the provision automatically cutting off certain authorities after 60 days unless they are extended by the Congress could work to prolong or intensify a crisis. Until the Congress suspended the deadline, there would be at least a chance of United States withdrawal and an adversary would be tempted therefore to postpone serious negotiations until the 60 days were up. Only after the Congress acted would there be a strong incentive for an adversary to negotiate. In addition, the very existence of a deadline could lead to an escalation of hostilities in order to achieve certain objectives before the 60 days expired. ${ }^{118}$

If passed, Nixon threatened that the resolution would also "strike from the

President's hand a wide range of important peacekeeping tools by eliminating his ability to exercise quiet diplomacy backed by subtle shifts in our military deployments." And finally, "it would give every future Congress the ability to handcuff every future President merely by doing nothing and sitting still." ${ }^{119}$ President Nixon, over the course of several days would plead to the American people the unconstitutionality of the resolution, on behalf of a strong Executive Branch.

Despite pleas from the President, Congress voted to override his veto on November 7-a response indicative of the overwhelming desires to put an end to the

${ }^{118}$ Ibid, 8.

${ }^{119}$ Ibid. 
'imperial presidency'. The vote count was 284-135 in the House and 75-18 in the Senate. Pat Holt, chief of staff of the Senate Foreign Relations Committee from 1974-1977, commented that although there were fluctuations in the number of Congressional members voting, there was a steady erosion of support for the President. ${ }^{120}$ This loss Holt attributes to growing unpopularity of the war in Vietnam compounded by the unfolding Watergate scandal. On the eve of the Saturday Night Massacre, Nixon's political fortunes were at their lowest point to that time.

In agreement with Holt, it is clear that the sentiment in the House was changing before the Saturday Night Massacre. The movement between the House bills in 1970 to the House bill in 1973 showed a dramatic shift in decreasing support for the Nixon Administration. The previous Senate War Powers bill in 1972 was turned down. A year later, the House approved the War Powers Resolution, and not by a small margin. This shift, Holt largely attributes to the unpopularity of the war in Vietnam. The Presidential veto was only overridden by a margin of 4 votes out of 419 cast. ${ }^{121}$ Holt raises the question whether those four votes would have stayed with the President in the absence of the Saturday Night Massacre, or whether the surge of antiwar sentiment would have been sufficient. It is apparent we will never know the result of Vietnam's impact on the presidency in the absence of the Watergate scandal, or vice versa-the impact of the Watergate scandal's on the presidency in the absence of the Vietnam war; however, what is important is the dramatic impact each had on Congress, the President, and the way the American people viewed the presidency.

\footnotetext{
${ }^{120}$ Ibid.

${ }^{121}$ Ibid, 9 .
} 


\section{CONSTITIONAL CONTROVERSY-THE BALANCE OF POWER}

A prime area of concern since the passage of the War Powers Resolution has been whether or not the resolution violates the President's power as Commander-in-Chief of the United States Armed Forces. The section most cited as unconstitutional is Section 5(c), the section that contains the time requirements on the President committing troops, and 90 days for a declaration of war, otherwise the President may be forced to remove the armed forces if Congress passes a concurrent resolution. Many scholars note that this controversial section has already been rendered invalid by the Supreme Court's 1983 decision in INS v. Chadha. ${ }^{122}$ Although the facts of the case do not relate to the war powers, the findings of the Court directly impacted Section 5(c). ${ }^{123}$ In the majority decision, Chief Justice Burger contended that "Congress must abide by its delegation of authority to the Attorney General until that delegation is legislatively altered or revoked. Finally, the veto's legislative character is confirmed by the fact that when the Framers intended to authorize either House of Congress to act alone and outside of its prescribed bicameral legislative role, they narrowly and precisely defined the procedure for such action in the Constitution." ${ }^{24}$ In summation, the Court decided that Congress may not

\footnotetext{
${ }^{122}$ U.S. 919 IMMIGRATION AND NATURALIZATION SERVICE v. CHADHA 462 U.S. 919 (1983).

${ }^{123}$ In INS v. Chadha, the respondent Jagdish Rai Chadha was born in Kenya to Indian parents, but neither Kenya nor India recognized him as a legitimate citizen or resident. He traveled to Ohio as a foreign exchange student. After his nonimmigrant student visa expired, neither Kenya nor India would accept him back into the country. The INS was to deport him. Chadha suspended his deportation. The House of Representatives vetoed his suspension and Chadha was to be deported. The principle argument of the case is that a one-house legislative veto violated the constitutional separation of powers.

${ }^{124}$ INS v. Chadha.
} 
invent unconstitutional devices, such as the invention of a veto, as a means to reign in excessive exercises of presidential power. ${ }^{125}$

In question of the constitutionality of the War Powers Resolution, it is difficult to come to an agreement. Although INS v. Chadha the Supreme Court's ruling struck down (arguably) Section 5(c), this was done so indirectly, through the ruling of the majority opinion—not as a direct means of dealing with the separation of powers. In Duncan $v$. Kahanamoku, ${ }^{126}$ a prior Court decision that ruled on the separation of powers, the dissenting opinion on the Court seemed to characterize the feelings the Court has pursued in ruling on such key issues. Justice Burton warned:

It is important... that in reviewing the constitutionality of the conduct of our agencies of government in time of war, invasion or threatened invasion, we do not now make precedents which in other emergencies may handicap the executive branch of the Government in the performance of duties allotted to it by the Constitution and by the exercise of which it successfully defended the nation against the greatest attack ever made upon it. ${ }^{127}$

In 1983, the administration of President Ronald Reagan felt that Congress was too intrusive on foreign policy as a result of the War Powers Resolution. "The feeling is that Congress is going too far. Every detail of foreign policy is now being fully scrutinized down to the minutiae. We're dealing with committee reports that are often conflicting, which makes it very difficult for the execution of foreign policy." ${ }^{128}$ In the opinion of the

\footnotetext{
${ }^{125}$ Abraham D. Sofaer, Henry Bartholomew Cox, War, Foreign Affairs, and Constitutional Power: 18291901. (Ballinger Publishing Company: Cambridge, 1984), xix.

${ }^{126}$ In Duncan v. Kahanamoku, Duncan was arrested in Hawai'i for public intoxication and tried by military tribunal. As a civilian he was tried under military tribunal because after the bombing of Pearl Harbor, Hawai'i suspended the writ of habeas corpus and placed the state under martial law. The Supreme Court ruled that the authorization of martial law did not include the power to supplant civilian courts with military tribunals.

${ }^{127}$ Clinton Rossiter, The Supreme Court and the Commander in Chief (Da Capo Press: New York, 1970), 128.

${ }^{128}$ Steven V. Roberts, “The Focus Turns to Foreign Policy," New York Times, May 3, 1983, ProQuest Historical Newspapers, D26.
} 
Reagan administration, and the administrations before and after him, the balance of power had swung dangerously to the legislative side. 


\section{WAR POWERS RESOLUTION IMPLEMENTATION}

Between 1975 and November 15, 2004, Presidents have submitted 115 reports as the result of the War Powers Resolution. ${ }^{129}$ President Ford submitted four reports, President Carter one, President Reagan fourteen, and President George H. W. Bush six reports. President Clinton submitted 86 reports. President George W. Bush submitted 29 reports. ${ }^{130}$ Of the reports submitted, only one cited Section Four which triggers the time limit. $^{131}$

Time and time again, the President, Congress, and the courts have proven unwilling to trigger the War Powers Resolution mechanism. In light of its inability to be consistently used, there have been three options invoked by members of the government and intellectual community. The first option holds that the resolution restricts the power of the President in foreign policy and should be repealed altogether. Supporters of repeal content that the President needs flexibility in the conduct of foreign policy and that the time limitation in the War Powers Resolution is unconstitutional and impractical. A conversation between Senator Javits and Senator Barry Goldwater demonstrates some of the concern with the impact the resolution has on the executive,

SENATOR JAVITS. So you really are opposed to my bill because you have less faith in the Congress than you have in the President; isn't that true?

SENATOR GOLDWATER. To be perfectly honest with you, you are right. ${ }^{132}$

\footnotetext{
${ }^{129}$ Richard F. Grimmett, "The War Powers Resolution: Presidential Compliance," (CRS Report for Congress. November 15, 2004), 1 .

${ }^{130}$ Ibid, i.

${ }^{131}$ At the time when the report was turned in, the military action was completed and United States Armed Forces had disengaged from the area of conflict.

${ }^{132}$ Holt, 35.
} 
An alternate perspective for the repeal is that Congress has always had the power, through appropriations and general lawmaking, to inquire into, support, limit, or prohibit specific uses of U.S. Armed Forces if there is majority support. The War Powers Resolution does not fundamentally change this equation, but instead it complicates action, misleads military opponents, and diverts attention from key policy questions. ${ }^{133}$

On the other side of the aisle, there are members of Congress who assert that the War Powers Resolution has been effective by increasing legislative-executive communication and congressional leverage. The resolution has served as a restraint on the use of armed forces by the President in some cases because of awareness that certain actions might invoke its provisions. Examples for this position include, the threat of invoking the War Powers Resolution may have been helpful in getting U.S. forces out of Grenada, in keeping the number of military advisers in El Salvador limited to 55, and in prodding Congress to take a stand on authorizing the war against Iraq. ${ }^{134}$ Professor of public policy and guest journalist for the New York Times, I.M. Destler, is in agreement with this perspective. He asserts that the War Powers Resolution "challenged, and then vanquished, Richard M. Nixon, Gerald R. Ford, and Henry Kissinger."135 John W. Finney also wrote in the New York Times that since the War Powers Resolution was passed, there has been evidence of a changing relationship between Congress and the White House on sharing war-making powers. ${ }^{136}$ In a follow-up piece written in 1979 , Finney concludes that although the resolution had not been thoroughly tested, Congress

\footnotetext{
${ }^{133}$ Grimmett, 48.

${ }^{134}$ Ibid.

${ }^{135}$ I.M. Destler, “Unruly, Fragmented Congress Wears Down President's Foreign Policy,” New York Times, October 25, 1981, ProQuest Historical Newspapers, E3.

${ }^{136}$ John W. Finney, "President's Power: Tonkin and Today," New York Times, April 25, 1975, ProQuest Historical Newspapers, 13.
} 
was headed in the right direction in terms of the balance of power. "When President Carter decided several weeks ago to send a squadron of F-15 fighters to Saudi Arabia in a show of force and support, the plane went unarmed, partly because of the concern that if they were armed, the President would be in violation of the War Powers Resolution if he did not immediately inform Congress."137

And finally, somewhere in the middle, the third view is that the War Powers Resolution has not been adequate to accomplish its objectives and needs to be strengthened or reshaped. Proponents of this view assert that Presidents have continued to introduce United States Armed Forces into hostilities without consulting Congress and without congressional authorization. There are numerous potential amendments; some of the main arguments include returning to the original Senate version of the War Powers Resolution. As discussed earlier, the House bill was much more dramatic and the conference compromised on the bill. Returning to the original Senate version has been proposed several times, the first in 1977 by Senator Thomas Eagleton. A return to the original version would require prior congressional authorization for the commitment of forces into conflict abroad without a declaration of war (except in the circumstance of to respond to or forestall an attack upon the United States or its forces or to protect U.S. citizens while evacuating them). This contention would also eliminate the 60-90 day period the President has to act militarily without congressional authorization.

Another proposed amendment is to shorten or eliminate altogether the time period that the President could maintain forces in hostile situations abroad without congressional approval. Proponents of this amendment contend the current resolution gives the

\footnotetext{
${ }^{137}$ John W. Finney, "War Powers Pendulum Swings Back-A Little.” New York Times, April 8, 1979, ProQuest Historical Newspapers, E5.
} 
President 60 to 90 days to do as he chooses and that this provides too much opportunity for mischief of irreversible action. ${ }^{138}$ Prohibiting the obligation or expenditure of funds for any use of U.S. armed forces in violation of the resolution or laws passed under it is another option those in favor or amending the War Powers Resolution advocate.

Perhaps one of the most compelling amendments to the resolution involves establishing a consultation group in Congress. Complaints made in the years following the resolution's passage included that there was no set guideline on what consultation meant. Representative John B. Anderson of Illinois, the third-ranking Republican in the House said he was disappointed that "Mr. Ford had done no more than "calling up and saying here's what we've decided.' That doesn't really fit the new era of divided responsibility." 139 In the same situation involving President Ford, the Senate Democratic leader Mr. Nessan said, "I was not consulted. I was notified after the fact about what the Administration had already decided to do." ${ }^{140}$

The War Powers Resolution was passed in an effort to provide clarification on the balance of power between the President and Congress. Never the less, it is clearly impractical for the President to consult with 535 members of Congress. Considerations of time and security argue that the list of the chosen for consultation be short. ${ }^{141}$ Senators Byrd, Nunn, Warner, and Mitchell have proposed the President regularly consult with an initial group of 6 members - the majority and minority leaders of both Chambers plus the Speaker of the House and President pro tempore of the Senate. ${ }^{142}$ Additionally, after the

\footnotetext{
${ }^{138}$ Grimmett, 49.

${ }^{139}$ David E. Rosenbaum, "But Some Note the Law Requires Consultations," New York Times, May 16, 1975, ProQuest Historical Newspapers, 15.

${ }^{140}$ Philip Shabecoff, "Ford is Backed: Senate Unit Endorses His Right of Order Military Action," New York Times, May 15, 1975, ProQuest Historical Newspapers, 89.

${ }^{141}$ Holt, 34.

${ }^{142}$ Senate Joint Resolution 323, introduced May 19, 1988.
} 
initial meeting, the President is to consult with a permanent group of 18 members consisting of the leadership and the ranking and minority members of the Committees on Foreign Relations, Armed Services, and Intelligence. This group will be able to determine whether the President should have reported an introduction of forces and to introduce a joint resolution of authorization or withdrawal that would receive expedited procedures. Further defining what the consultation and communication between the President and Congress should look like can only help to strengthen the resolution. 


\section{CONCLUSION}

In the view of many of its supporters, the War Powers Resolution was nothing more than an attempt to restate and thereby reassert what they considered to be the original powers of Congress, powers which had atrophied through lack of use. ${ }^{143}$ At the same time, the resolution provided a procedure for the exercise of these powers in the future. It is a procedure, furthermore, designed to force Congress to act, either to approve or to end any long-term U.S. military involvement abroad. The War Powers Resolution was enacted to make it more difficult for Congress to acquiesce in future situations like Vietnam.

The Supreme Court has so often abstained from hearing cases addressing the separation of powers between the President and Congress, especially regarding the issue of war powers. It has been the Court's position that the contours of the presidential war powers have been presidentially, not judicially, shaped; their existence is for Congress and the people, not the Court, to oversee. ${ }^{144}$ In agreement with Rossiter, if the Supreme Court would be a little more clear voiced about the general power of this nation to make war, "it could turn around and deliver a great deal more relief in specific instances of individual injustice, which was all it was supposed to do in the first place... the less it pretends, the more it can defend." 145 Although it is unclear exactly how the Court would rule-more in favor of Congress or more in favor of the President (depending on the composition of the Court at the time), or potentially setting precedent for a more true

\footnotetext{
${ }^{143}$ Holt, 40.

${ }^{144}$ Rossiter, 126.

145 Ibid, 130.
} 
balance of powers, one can argue that clarification on the issue would be in service of all three branches of government.

There have been few Supreme Court decisions directly addressing the executive war powers. Legal scholars, Ann and A.J. Thomas remind us that in the absence of Court rulings, one must look at extraconstitutional history to resolve the issue of war powers, "for our government developed not only from constitutional interpretation by the court, but also from past precedents and actions of both the executive and legislative branches." 146 With this idea of extraconstitutional history, it is easy to apply it to recent presidential administrations and wonder why Congress has not taken greater action in an effort to not repeat blunders in history. The most obvious example is the correlation often made between the Vietnam War and the Iraq War that was started in 2002 under President George W. Bush. Neither war was ever declared by Congress, and yet exceptional numbers of United States Armed Forces were committed to these locations. The Vietnam War was authorized by Congress initially under the Gulf of Tonkin Resolution, and the Iraq War was authorized by Congress under the Authorization for Use of Military Force Against Iraq Resolution of 2002. ${ }^{147}$ Each authorization of military force was initially supported, and as the conflict progressed, became increasingly more and more unpopular with the American public.

As stated before, it is unfortunate that the legislative branch seems to lack the confidence in their own information and judgments and therefore, is likely to be intimidated by the executive authority. Even in the face of a greatly unpopular conflict, Congress has not executed its authority under the Constitution, reaffirmed by the War

\footnotetext{
146 Thomas, 117.

${ }^{147}$ H.J. Res. 114, Pub.L. 107-243. October 16, 2002.
} 
Powers Resolution, to withdraw funds, and requires that under Section Five that the President remove armed forces. This was never executed during the Vietnam War and has not been executed since. Prior to the passage of the War Powers Resolution, Congress was attempting to create a bill that would force an early end to the role of the United States in Southeast Asia. Although Congress and the American people appeared ready to end United States participation, the trouble with setting a withdrawal date came from the large number of American prisoners of war that were being held in North Vietnam. ${ }^{148}$ If the United States were to create an absolute deadline for troop removal the prisoners would be at the mercy of the North Vietnamese. Instead, the language of the bill was changed to the United States should terminate military operations in Southeast Asia "at the earliest practicable date." 149 In similar fashion, Congress attempted to create a timetable for troop withdrawals in Iraq beginning in 2007-the U.S. Troop Readiness, Veterans' Health, and Iraq Accountability Act of 2007 (H.R.1591). Congress was able to pass this bill, and within the bill was a call for complete withdrawal of U.S. combat soldiers by September 1, 2008. President Bush vetoed the bill on March 1, 2007, and Congress was unable to come up with the necessary two-thirds to override the veto. The war in Iraq has proven another example of Congressional inability to use the tools they have been provided — the U.S. Constitution and the War Powers Resolution of 1973. The evolution of American foreign policy brought the United States and the American presidency to its status in the 1970s. As Schlesinger put it, "The American presidency has come to see itself in messianic terms as the appointed savior of a world whose unpredictable dangers call for rapid and incessant deployment of men, arms, and

\footnotetext{
148 Thomas, 124.

${ }^{149}$ Ibid.
} 
decisions behind a wall of secrecy. This view seems hard to reconcile with the American Constitution."

In the absence of the Presidents of the twentieth century constantly building upon one another's involvement in world affairs, it is nearly impossible to assert that Richard Nixon would have taken the presidency to an imperial level all on his own. What is certain, however, is that the passage of the War Powers Resolution of 1973 was a result of President Richard Nixon's policies—both domestic and foreign. President Nixon's blunders in the Watergate affairs at home, and his involvement in the Vietnam conflict that cost tens of thousands of American lives, and countless more Asian lives, prompted Congress to unite and pass a resolution limiting the scope of the President's war-making ablities.

There are historians that argue that the Founding Fathers did not create a Constitution with shared war powers among the President and Congress. Supporters of this argument like David Locke Hall argue that each branch has its own powers, separate and distinct, which affect the legal authority to wage war. ${ }^{151}$ I think this concept is easily dispelled. If the Constitution was laid out with clear cut lines of the roles of Congress and the President, there would not be a continual struggle in the balance of power between the two branches. If it was as clear cut as Hall attempts to portray it, it would be easy for the Supreme Court to rule on the nature of the powers that the executive and legislative branches possess, and both Congress and the President would understand their limitations without exceeding or undercutting them-but clearly this has not proven to be the case. Instead, the twentieth century struggle to prevent further development of an imperial

\footnotetext{
${ }^{150}$ Schlesinger, 66.

${ }^{151}$ Hall, 22.
} 
presidency has carried into the twenty first century. Although the War Powers

Resolution has been referenced by Presidents in over one hundred circumstances since its passage, it has not served the purpose that Senator Jacob Javits originally claimed—to rebalance Congressional and Presidential war powers. 


\section{Bibliography}

\section{Primary Sources}

Berger, Raoul, “The Mayaguez Incident and the Constitution," New York Times (1857Current file); May 23, 1975; ProQuest Historical Newspapers The New York Times (1851-2005) pg. 37.

Carl, Bernstein, Bob Woodward, All the President's Men. New York: Simon \& Schuster, Inc., 1974.

Destler, I.M., "Unruly, Fragmented Congress Wears Down President's Foreign Policy," New York Times (1857-Current file); October 25, 1981; ProQuest Historical Newspapers The New York Times (1851-2005) pg. E3.

Drew, Elizabeth, “The Capital's Liberation: A Dismal Image Fades," New York Times (1857-Current file); May 11, 1975; ProQuest Historical Newspapers The New York Times (1851-2005) pg. E1.

Finney, John W., "President's Power: Tonkin and Today," New York Times (1857Current file); April 25, 1975; ProQuest Historical Newspapers The New York Times (1851-2005) pg. 13.

Finney, John W., "War Powers Pendulum Swings Back-A Little.” New York Times (1857-Current file); April 8, 1979; ProQuest Historical Newspapers The New York Times (1851-2005) pg. E5.

Gwertzman, Bernard, "President Vetoes Aid Bill, Charging it Restricts Him," New York Times (1857-Current file); May 8, 1976; ProQuest Historical Newspapers The New York Times (1851-2005) pg. 1

Gwertzman, Bernard, "U.S. Attempt to Rescue Iran Hostages Fails; 8 Die as Planes Collide During Withdrawal," New York Times (1857-Current file); April 25, 1980; ProQuest Historical Newspapers The New York Times (1851-2005) pg. A1.

Jackson Jr., William E., "A Senate Blockade Could Stop the War," New York Times (1857-Current file); June 20, 1972; ProQuest Historical Newspapers The New York Times (1851-2005) pg. 38.

Javits, Jacob K., "Events Show We Can Live With War-Powers Curbs," New York Times (1857-Current file); October 1, 1982; ProQuest Historical Newspapers The New York Times (1851-2005) pg. C7.

Kissinger, Henry, White House Years. Boston: Little, Brown and Company, 1979. 
Kissinger, Henry, Years of Upheaval. Boston: Little, Brown and Company,

Kraft, Joseph, “The Post-Imperial Presidency,” New York Times (1857-Current file); November 2, 1980; ProQuest Historical Newspapers The New York Times (18512005) pg. SM8.

Landau, David E., “Congress's War Powers-What Happened?" New York Times (1857Current file); December 3, 1980; ProQuest Historical Newspapers The New York Times (1851-2005) pg. A31

Lewis, Anthony, "Evil and Malice Shared," New York Times (1857-Current file); May 5, 1977; ProQuest Historical Newspapers The New York Times (1851-2005) pg. A27.

Nixon, Richard, The Memoirs of Richard Nixon: Volume One. New York: Warner Books Inc., 1978.

Nixon, Richard, The Memoirs of Richard Nixon: Volume Two. New York: Warner Books Inc., 1978.

Nixon, Richard M., "Vietnam: Decision to Resume Bombing: Nixon Memoirs, Part 4," New York Times (1857-Current file); May 3, 1978; ProQuest Historical Newspapers The New York Times (1851-2005) pg. B1.

Roberts, Steven V., "The Focus Turns to Foreign Policy," New York Times (1857Current file); May 3, 1983; ProQuest Historical Newspapers The New York Times (1851-2005) pg. D26.

Rosenbaum, David E., "But Some Note the Law Requires Consultations," New York Times (1857-Current file); May 16, 1975; ProQuest Historical Newspapers The New York Times (1851-2005) pg. 15.

Shabecoff, Philip, "Ford is Backed: Senate Unit Endorses His Right of Order Military Action," New York Times (1857-Current file); May 15, 1975; ProQuest Historical Newspapers The New York Times (1851-2005) pg. 89.

Sheppard Jr., Nathaniel, "Javits Will Propose Curbs on Powers of Presidency," New York Times (1857-Current file); April 28, 1974; ProQuest Historical Newspapers The New York Times (1851-2005) pg. 1.

Shribman, David, "New Questions Arise Over War Act," New York Times (1857-Current file); October 1, 1982; ProQuest Historical Newspapers The New York Times (1851-2005) pg. A8. 
Taylor, Maxwell D., “The Vietnam Disaster and U.S. Security,” New York Times (1857Current file); May 9, 1975; ProQuest Historical Newspapers The New York Times (1851-2005) pg. 35.

Tolchin, Martin, "Key Questions in Tug-of-War on War Powers," New York Times (1857-Current file); September 1983; ProQuest Historical Newspapers The New York Times (1851-2005) pg. 7.

Washington, George, George Washington's Farewell Address. Bedford: Appleewood Books, 1999.

“Only Legal Wars are Worthy Wars,” New York Times (1857-Current file); May 8, 1983; ProQuest Historical Newspapers The New York Times (1851-2005) pg. E16.

“Text of President Ford's Report to Congress on Ship," New York Times (1857-Current file); May 16, 1975; ProQuest Historical Newspapers The New York Times (1851-2005) pg. 15

“The War Powers Skirmish,” New York Times (1857-Current file); May 2, 1980;

ProQuest Historical Newspapers The New York Times (1851-2005) pg. A26.

U.S. 919 IMMIGRATION AND NATURALIZATION SERVICE v. CHADHA 462 U.S. 919 (1983).

“War Powers Resolution of 1973," 93 ${ }^{\text {rd }}$ Congress, H. J. Res. 542. November 7, 1973.

“Who Declares Secret Wars?” New York Times (1857-Current file); April 10, 1983; ProQuest Historical Newspapers The New York Times (1851-2005) pg. E20.

\section{Secondary Sources}

Abshire, David M., Ralph D. Nurnberger, The Growing Power of Congress. Washington D.C.: Sage Publications, 1981.

Barnhart, Michael, ed., Congress and the United States Foreign Policy: Controlling the Use of Force in the Nuclear Age. State University of New York Press: Albany, 1987.

Dallek, Robert, Partners in Power: Nixon and Kissinger. New York: Harper Collins Publishers, 2007.

Dorf, Michael C., No Litmus Test: Law Versus Politics in the Twenty-First Century. New York: Rowman \& Littlefield Publishers, Inc., 2006. 
Edwards III, George C., Stephen J. Wayne, Presidential Leadership: Politics and Policy Making. Washington D.C.: Thompson Wadsworth, 2006.

Ely, John Hart, War and Responsibility: Constitutional Lessons of Vietnam and its Aftermath. Princeton: Princeton University Press, 1993.

Fineman, Howard, The Thirteen American Arguments: Enduring Debates that Define and Inspire our Country. New York: Random House Publishing, 2008.

Fisher, Louis, Presidential War Power. University Press of Kansas: Lawrence, 2004.

Friedman, Leon, Burt Neuborne, Unquestioning Obedience to the President. New York: W.W. Norton and Company, 1972.

Grimmett, Richard F., The War Powers Resolution. New York: Novinka Books, 2002.

Hall, David Locke, The Reagan Wars: A Constitutional Perspective on War Powers and the Presidency. San Francisco: Westview Press, 1991.

Herring, George, From Colony to Superpower: U.S. Foreign Relations Since 1776. New York: Oxford University Press, 2008

Holt, Pat M., The War Powers Resolution: The Role of Congress in the U.S. Armed Intervention. Washington D.C.: American Enterprise Institute for Public Policy Research, 1978.

Isaacson, Walter, Kissinger: A Biography. New York: Simon \& Schuster Paperbacks, 1992.

Keynes, Edward, Undeclared War: Twilight Zone of Constitutional Power. University Park: Pennsylvania State University Press, 1982.

Lehman, John, Making War: The 200-Year-Old Battle Between the President and Congress over How America Goes to War. New York: Macmillan Publishing Company, 1992.

Lofgren, Charles A., "Government From Reflection and Choice,” Constitutional Essays on War, Foreign Relations, and Federalism. New York: Oxford University Press, 1986.

Moss, Kenneth B., Undeclared War and the Future of U.S. Foreign Policy. Baltimore: The Johns Hopkins University Press, 2008.

Rakove, Jack N., Original Meanings: Politics and Ideas in the Making of the Constitution. New York: Alfred A. Knopf, Inc., 1996. 
Rossiter, Clinton, The Supreme Court and the Commander in Chief. Da Capo Press: New York, 1970.

Schulzinger, Robert D., U.S. Diplomacy Since 1900. New York: Oxford University Press, 2002

Schlesinger, Jr., Arthur M., War and the American Presidency. New York: W. W. Norton \& Company, 2004.

Small, Melvin, The Presidency of Richard Nixon. Lawrence: University Press of Kansas, 1999.

Sofaer, Abraham D., War, Foreign Affairs, and Constitutional Power: The Origins. Cambridge: Ballinger Publishing Company, 1976.

Sofaer, Abraham D., Henry Bartholomew Cox, War, Foreign Affairs, and Constitutional Power: 1829-1901. Ballinger Publishing Company: Cambridge, 1984.

Thomas, Ann Van Wynen, The War-Making Power of the President: Constitutional and International Law Aspects. SMU Press: Dallas, 1982.

Turner, Robert F., Repealing the War Powers Resolution: Restoring the Rule of Law in U.S. Foreign Policy. New York: Macmillan Publishing Company, 1991

Turner, Robert F., The War Powers Resolution: Its Implementation in Theory and Practice. Philadelphia: Foreign Policy Research Institute, 1983.

\section{$\underline{\text { Videos }}$}

The President and the Constitution: Richard Nixon. 1991. Commission on the Bicentennial of the United States Constitution.

The President and the Constitution: Gerald R Ford. 1991. Commission on the Bicentennial of the United States Constitution.

\section{Journal Articles}

Farrar-Myers, Victoria A., "Transference of Authority: The Institutional Struggle Over the Control of the War Power," Congress \& the Presidency 25, no. 2: 183-197. America: History \& Life. 
Fisher, Louis, "Congressional Checks on Military Initiatives," Political Science Quarterly Volume 109 Number 5, 1994-95. 739-762.

Gartzke, Erik, "Congress and Backseat Driving: An Informational Theory of the War Powers Resolution,” Policy Studies Journal, Vol. 24, No. 2, 1996. 259-286.

Grimmett, Richard F., "The War Powers Resolution: After Twenty Eight Years," CRS Report for Congress: November 15, 2001.

Pious, Richard M., "Inherent War and Executive Powers and Prerogative Politics," Presidential Studies Quarterly 37, no. 1 (March). 2007.

"Nation: The Commitments Resolution," TIME Magazine. July 4, 1969. http://www.time.com/time/magazine/article/0,9171,8401642,00.html?artId=840164? cont Type=article? $\operatorname{chn}=u$ 